\title{
Immunological Response to the Prolonged Administration of Heterologous and Homologous Insulin in Cattle*
}

\author{
Albert E. Renold, $\nmid$ Jurgen Steinke, $\ddagger$ J. Stuart Soeldner,+ Harry N. \\ Antoniades, and Russell E. Smith \\ (From the Elliott P. Joslin Research Laboratory in the Department of Medicine, Harvard \\ Medical School, Boston, Mass., and the College of Agriculture, Department of \\ Veterinary Science, University of Massachusetts, Amherst, Mass.)
}

Soon after insulin was discovered in 1922 and made available for the treatment of patients with diabetes mellitus, the probable antigenicity of this biologically active protein was suspected. In 1928, the antigenic activity of the hormone was established by Tuft, using a highly purified recrystallized preparation of insulin (1). At that time, because immunization rarely produced precipitating antibodies, insulin was considered a relatively weak antigen. Subsequently, the development of techniques for the measurement of insulin antibodies and their wide use have demonstrated that a high incidence of serological changes followed prolonged administration of insulin. This topic has been reviewed extensively in recent years (2-5). The induction of an immunological response to insulin administration and its association with resistance to its physiological action were first demonstrated by Banting, Franks, and Gairns in 1938 (6) and have been repeatedly demonstrated since. Antiinsulin sera highly potent in their capacity to neutralize the hypoglycemic activity of insulin have been prepared in guinea pigs. These animals have been immunized with insulin of bovine or porcine origin, and these sera have been shown to neutralize bovine and porcine insulin as well as insulin from a number of other species (7-10). How-

* Submitted for publication August 18, 1965 ; accepted January 20, 1966.

Supported in part by grants-in-aid from the John A Hartford Foundation, Inc., New York, N. Y.; the Eli Lilly Co., Indianapolis, Ind.; the Adler Foundation, Inc., Rye, N. Y.; and the Diabetes Foundation, Inc., Boston, Mass.

$\dagger$ Address requests for reprints to Dr. Albert E. Renold, Institut de Biochimie Clinique, Université de Genève, Geneva, Switzerland.

$\ddagger$ Work done while supported by U. S. Public Health Service diabetes training grant 5T1 AM-5077. ever, the binding of insulin to its antibody and the neutralization of insulin activity are not necessarily synonymous.

All these studies have assumed that the antigenicity of insulin is related primarily to species difference. However, suitable control experiments, in which the insulin used for immunization was of the same species, have been reported only recently. Pancreatic insulin, extracted and purified for administration, may not be identical with circulating insulin, and therefore it should not be taken for granted that homologous insulin administered to the same species will not produce an immunological response. The present study was undertaken to compare, in the bovine species, the immunological responses to heterologous (porcine) and homologous (bovine) insulin administered over long periods of time. Some of the results of these studies have been reported in preliminary form $(11,12)$. Similar and entirely independent studies have been reported in the pig by Lockwood and Prout $(13,14)$ and also by Brunfeldt and Deckert (15).

\section{Methods}

Experimental animals. The 15 heifers used were purebred Holstein, Guernsey, Jersey, and Ayrshire breeds of comparable ages from the stock of the Department of Veterinary Science in the College of Agriculture at the University of Massachusetts. They were divided into three groups of five each. Five animals serving as controls received only injections of adjuvant, five animals received injections of crystalline porcine insulin in adjuvant, and five animals received injections of crystalline bovine insulin in adjuvant. Care was taken to achieve comparable distribution of the different breeds in each experimental group. The distribution of breeds, the initial weights, and base-line serum glucose levels are shown in Table $\mathrm{I}$.

Antigens. The insulin for injection assayed $24.8 \mathrm{U}$ per 
$\mathrm{mg}$ porcine insulin and $25.2 \mathrm{U}$ per $\mathrm{mg}$ bovine insulin. ${ }^{1}$ Both preparations were recrystallized five times and contained less than $0.1 \%$ glucagon. Special precautions were taken to avoid possibility of contamination of either insulin with insulin of the other species. Both preparations were obtained from pancreas collected separately and were handled as special lots, which are prepared in the following manner: for 3 to 5 days before the actual preparation of a special lot of either bovine or porcine insulin, beef (for bovine insulin) or pork (for porcine insulin) pancreas exclusively is run through the equipment to free the equipment of any contaminating material of the other species. This applies to the initial extraction step. The extract then is processed in a separate area with no other insulin preparation present. This is carried all the way to the crystallization step. It appears that with this procedure any contamination of the insulin of one species with insulin of the other is practically excluded. ${ }^{2}$

The material for injection was prepared as follows: $400 \mathrm{mg}$ insulin was dissolved in $50 \mathrm{ml}$ acidified phenol $(0.6 \%), \mathrm{pH} 2.6$, and mixed in a Waring blendor with 35 $\mathrm{ml}$ mineral oil and $15 \mathrm{ml}$ anhydrous lanolin. The control adjuvant was prepared in identical fashion, insulin being omitted. Separate and permanently labeled blendors, glassware, syringes, and needles were used for the preparations of adjuvant and of bovine or porcine insulin. This preparation did not inactivate insulin, as insulin activity could be extracted from the mixture several days after its preparation and assayed on rat adipose tissue, exhibiting full activity. The insulin dose was $150 \mathrm{U}$ per 100 pounds animal, injected subcutaneously in the lower anterior flank area at intervals of no less than 2 weeks, alternating sides. This was close to the maximal dose, since in a preliminary experiment the administration of $300 \mathrm{U}$ per 100 pounds resulted in hypoglycemia that caused the death of one animal.

Sampling. Blood was obtained from the jugular vein twice before the first injection, and thereafter at regular intervals, usually 2 weeks. The sera were harvested and kept frozen until used.

Insulin antibody testing in vitro. The occurrence of an immunological response to insulin was determined by examining the electrophoretic distribution of insulin- ${ }^{182}$ I added to serum, with cellulose acetate as the supporting medium according to the general procedure recommended by Freedlender, Rees, and Soeldner (16). The iodinated insulin was either of bovine or porcine origin, with specific activities varying between 4 and $30 \mathrm{mc}$ per mg. ${ }^{3}$ Purity of every shipment was assessed by electrophoresis on cellulose acetate of the insulin- ${ }^{120}$ I diluted in buffer. All shipments not demonstrating more than $95 \%$ migration of activity in an area corresponding to $\alpha_{1}$-albu-

1 Lots 723603 and 719106, respectively. Obtained through the courtesy of the Lilly Research Laboratories, Indianapolis, Ind.

$2 \mathrm{We}$ are indebted for this information to Drs. W. R. Kirtley and W. N. Shaw.

3 Abbott Laboratories, North Chicago, IIl.
TABLE I

Breeds, initial ages, weights, and serum glucose values of animals used in this study

\begin{tabular}{|c|c|c|c|c|c|}
\hline \multirow[b]{2}{*}{ Breed } & \multirow[b]{2}{*}{ No. } & \multirow[b]{2}{*}{ Age* } & \multirow[b]{2}{*}{ Weight*† } & \multicolumn{2}{|c|}{ Serum glucose* } \\
\hline & & & & $5 / 10 / 62$ & $5 / 17 / 62$ \\
\hline & & months & $l b$ & \multicolumn{2}{|c|}{$m g / 100 m l$} \\
\hline \multicolumn{6}{|c|}{ Adjuvant (control) group } \\
\hline Holstein & 218 & 5 & 284 & 80 & 84 \\
\hline Holstein & 221 & 4 & 266 & 77 & 91 \\
\hline Guernsey & 212 & 5 & 240 & 102 & 106 \\
\hline Ayrshire & 155 & 10 & 410 & 77 & 86 \\
\hline Jersey & 136 & 12 & 513 & 86 & 80 \\
\hline \multicolumn{6}{|c|}{ Porcine insulin-immunized group } \\
\hline Holstein & 209 & 10 & 552 & 89 & 84 \\
\hline Holstein & 215 & 6 & 394 & 88 & 96 \\
\hline Holstein & 220 & 4 & 248 & 90 & 80 \\
\hline Guernsey & 211 & 5 & 250 & 93 & 91 \\
\hline Jersey & 135 & 12 & 526 & 86 & 91 \\
\hline \multicolumn{6}{|c|}{ Bovine insulin-immunized group } \\
\hline Holstein & 210 & 10 & 513 & 93 & 81 \\
\hline Holstein & 217 & 6 & 384 & 90 & 87 \\
\hline Holstein & 219 & 4 & 275 & 86 & 91 \\
\hline Guernsey & 210 & 5 & 257 & 80 & 99 \\
\hline Jersey & 134 & 12 & 570 & 93 & 96 \\
\hline
\end{tabular}

* At beginning of experiment.

$\dagger$ Estimated by measuring tape.

min were discarded. Serum $(0.5 \mathrm{ml})$ was mixed with $0.05 \mathrm{ml}$ of insulin-181 diluted with barbital buffer, $\mathrm{pH}$ 8.6 and ionic strength 0.075 , to which human serum albumin had been added to a final concentration of $0.25 \mathrm{~g}$ per $100 \mathrm{ml}$. The total amount of insulin- ${ }^{181} \mathrm{I}$ added varied between 1,500 and 4,000 $\mu \mathrm{U}$ per $\mathrm{ml}$ of serum and is indicated in each graph or table. Varying the concentration of insulin- ${ }^{131} \mathrm{I}$ over this range did not significantly change the degree of distribution. After incubation overnight at $4^{\circ} \mathrm{C}, 3$ to $5 \mu 1$ of this mixture was applied to a cellulose acetate strip $(2.5 \times 16 \mathrm{~cm})$ and subjected to electrophoresis in a closed cell at room temperature for 6 hours in barbital buffer, $\mathrm{pH} 8.6$ and ionic strength 0.075 , at a constant current of 1.0 ma per strip. The strips were then dried for 20 minutes at $80^{\circ} \mathrm{C}$ and stained with Ponceau S $(0.2 \mathrm{~g}$ per $100 \mathrm{ml})$ in $3 \%$ trichloroacetic acid (TCA).

The distribution of the radioactivity on the strips was recorded by scanning and radioautography. Scanning was carried out in a Nuclear-Chicago actigraph II with 2- or 4-pi geometry, a collimator setting of $\frac{1}{8}$ inch, and a scanning speed of 12 inches per hour, with simultaneous rate metering and electronic integration of the counts. Radioautography was carried out by direct contact with Kodak Royal Blue X-ray film using an exposure of 5 days and standard development procedures. The immunological response was assessed by determining the total activity of each strip and relating the amount of the activity migrating in the $\beta-\gamma$ region as a per cent of the total.

Insulin antibody testing in vivo. Insulin ${ }^{101} \mathrm{I}$ in a dose of $800 \mu \mathrm{c}$ per animal was injected intravenously. Blood samples were obtained 12 minutes later, when mixing in the blood was considered to be complete, and 1,2, and 4 hours thereafter. Serum was precipitated and washed 


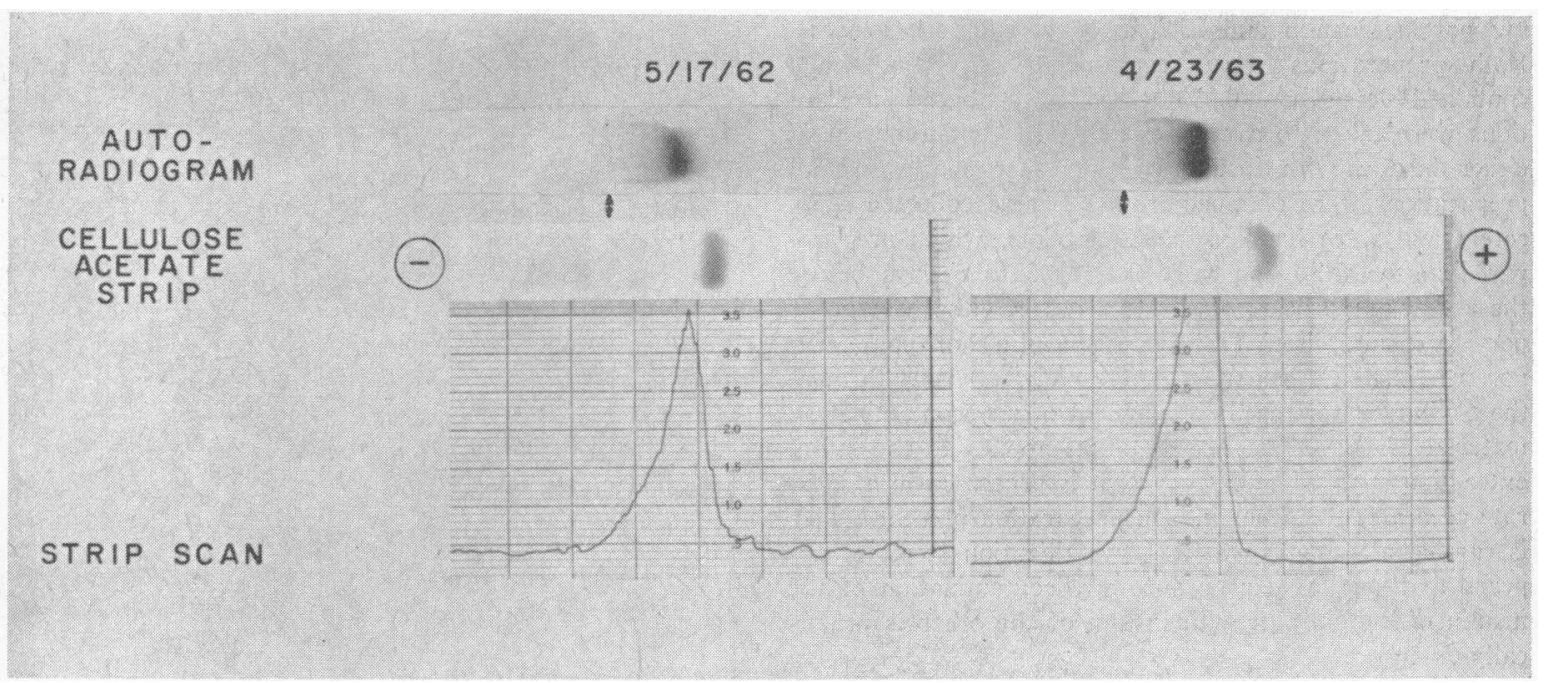

Fig. 1. Migration of PORCINE INSUlin ${ }^{181}$ I $(1,750 \mu$ U PER ML SERUM) DURING ELECTROPHORESIS ON CELlULOSE ACE-

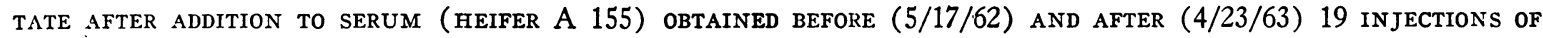
ADJUVANT ALONE.

with $10 \%$ trichloroacetic acid, and the precipitable radioactivity was measured in a Nuclear-Chicago well counter.

Insulin tolerance tests were carried out by the intravenous administration of $0.1 \mathrm{U}$ insulin per kilogram body weight. Blood samples were collected twice before the injection and after 30,60, 90, and 120 minutes for determination of blood glucose according to Somogyi (17). Intravenous glucose tolerance tests were carried out by injecting, as rapidly as possible, $0.5 \mathrm{~g}$ glucose per kilogram body weight and using a $50 \%$ glucose solution and plastic squeeze bags for the injections. Blood samples for glucose were obtained before and 20, 40, 60, and 120 minutes after the beginning of the injection, which usually lasted 10 minutes. Serum insulin-like activity (ILA) was estimated on serum diluted 1 to 4 with buffer (25\% serum) with the rat epididymal adipose tissue technique previously described (18). In some instances, ILA was extracted from serum by an acid ethanol procedure, previously described (19).

\section{Results}

Heifers injected with adjuvant alone. Adjuvant was injected usually every other week in all five animals in this group from May to November of 1962, and in two animals from December 1962 to April 1963. The electrophoretic distribution of bovine and porcine insulin-131 I added to sera of these animals was examined throughout this period in approximately 90 samples. In all instances the distribution of insulin- ${ }^{131}$ I among serum proteins separated by cellulose acetate electrophoresis was that characteristic of free insulin migrating between albumin and the $\alpha_{1}$-globulins, with minimal trailing from the point of application. Figure 1 shows pertinent data of one animal typical of this group.

Heifers injected with porcine insulin in adjuvant. Adjuvant that contained porcine insulin was administered usually every other week in all five animals of this group from May to August 1962, for a total of seven injections. Insulin-131I incubated with the sera of these animals exhibited affinity for the proteins of the $\beta-\gamma$-globulin region 2 weeks after the first injection in four animals, and in the fifth animal 4 weeks after the first, i.e., 2 weeks after the second injection. An example for one heifer is shown in Figure 2. A summary of all determinations made throughout 1 year in this group of animals with porcine and bovine insulin-131 I is shown in Figure 3. Furthermore, Figure 3 shows that, from the beginning, affinity of insulin- ${ }^{131}$ I for the $\beta$ - $\gamma$ region could be demonstrated for both labeled porcine and bovine insulin, although the affinity for porcine insulin was greater.

Heifers injected with bovine insulin in adjuvant. Adjuvant containing bovine insulin was administered usually every other week in all five animals of this group from May to October 1962 for a total of 11 injections. Two of this group received eight additional injections 2 to 3 weeks apart from December 1962 to April 1963. Ini- 


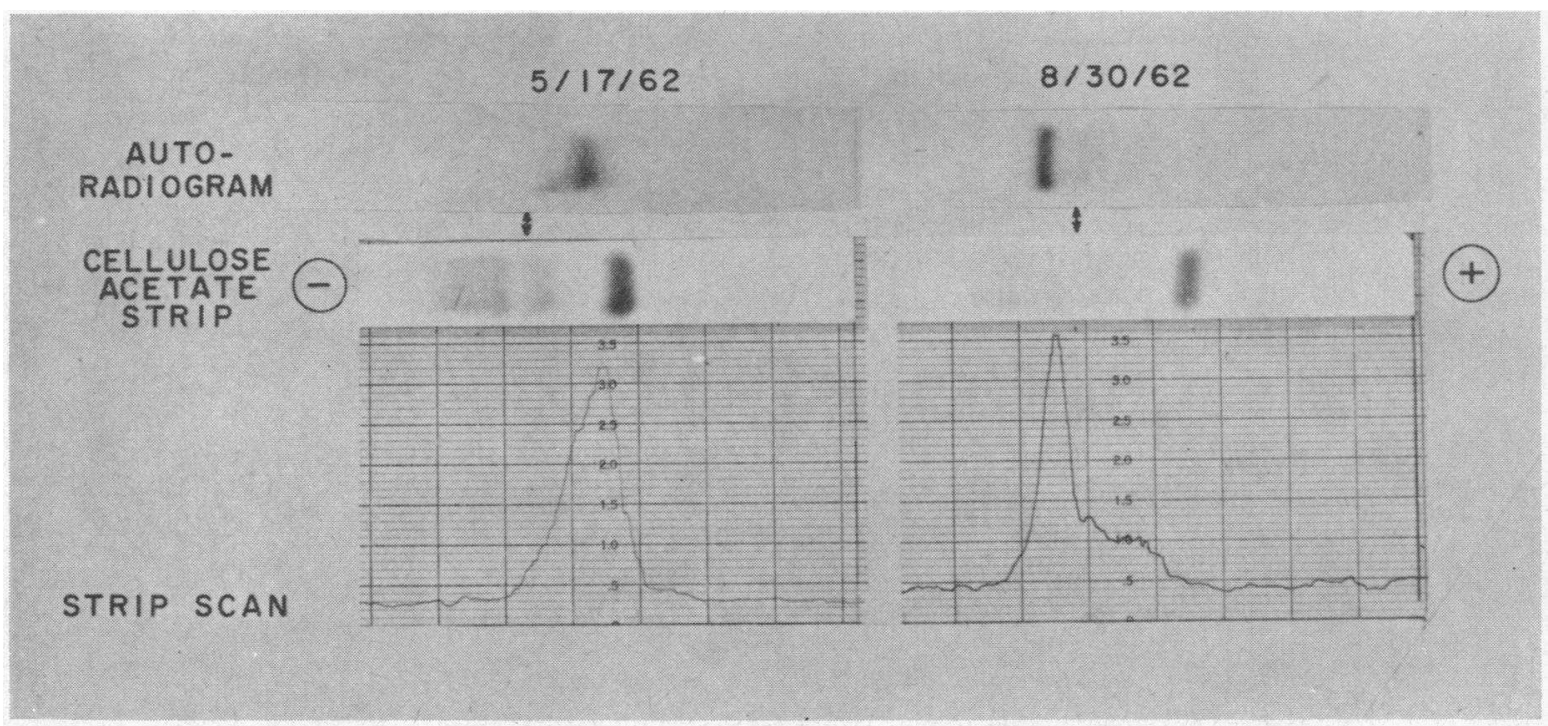

Fig. 2. MIGRATION OF PORCINE INSULIN- ${ }^{12 I}$ (1,750 $\mu$ U PER ML SERUM) DURING ELECTROPHORESIS ON CELLULOSE ACETATE AFTER ADDITION TO SERUM (HEIFER H 215) OBTAINED BEFORE (5/17/62) AND AFTER (8/30/62) SEVEN INJECTIONS OF PORCINE INSULIN IN ADJUVANT.

tially, sera of these animals did not exhibit $\beta-\gamma$ distribution of added bovine or porcine insulin${ }^{131}$ I. After three injections, 6 weeks after the first, a small amount of radioactivity was detected in the $\beta-\gamma$ region of sera obtained from two of the five animals. Several weeks later $\beta-\gamma$ distribution of radioactivity was detected in two more animals. The remaining animal $(\mathrm{H} 217)$ did not show this

ANIMALS: $\mathrm{H} 209, \mathrm{H} 215, \mathrm{H} 220, \mathrm{G} 211$, \& J135 INJECTIONS : PORCINE INSULIN $\times 7$

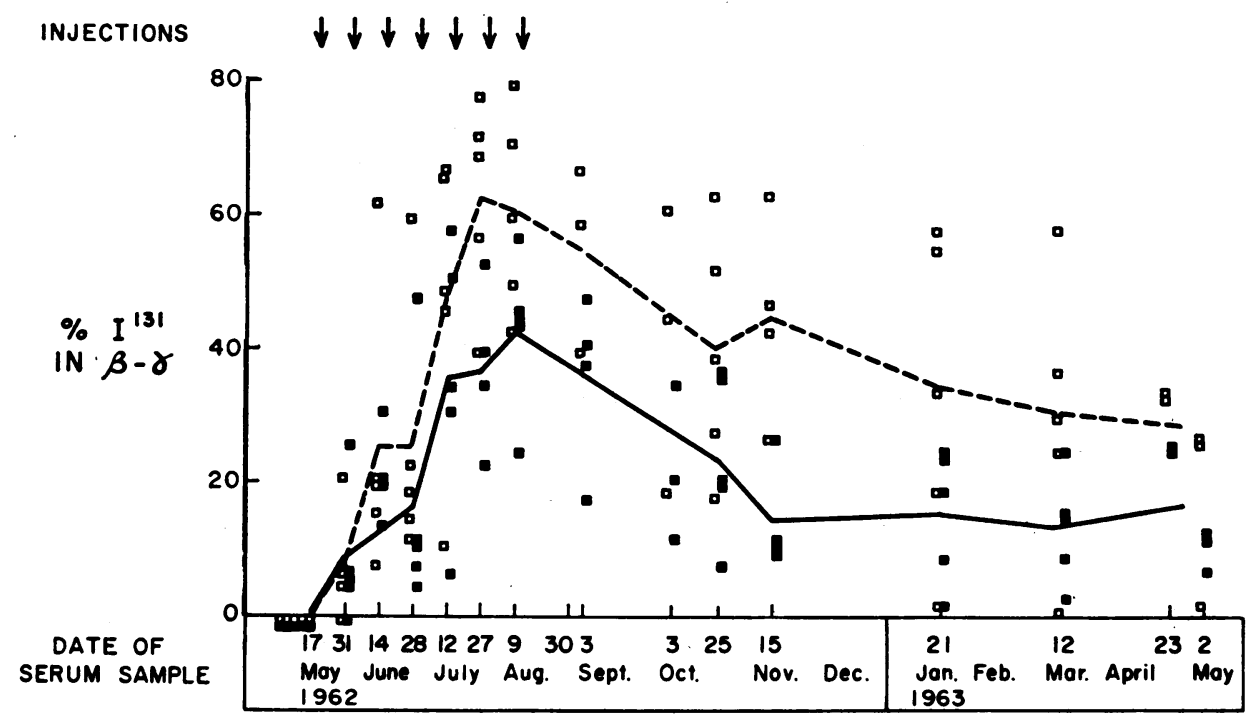

Fig. 3. Migration of ${ }^{181}$ I-LAbELED bovine ( $\boldsymbol{\square}$ ) OR PORCINE ( $\square$ ) INSUlin DURING ElectroPHORESIS ON CELLULOSE ACETATE AFTER ADDITION TO SERA FROM FIVE HEIFERS RECEIVING INJECTIONS OF PORCINE INSULIN IN ADJUVANT. Each small square shows the percentage of added labeled hormone (1,750 to $4,250 \mu \mathrm{U}$ per $\mathrm{ml}$ serum) migrating with the $\beta$ - $\gamma$-globulins, and the lines represent the mean values during the course of the experiment for added labeled porcine $(--)$ and bovine $(-)$ insulins. 


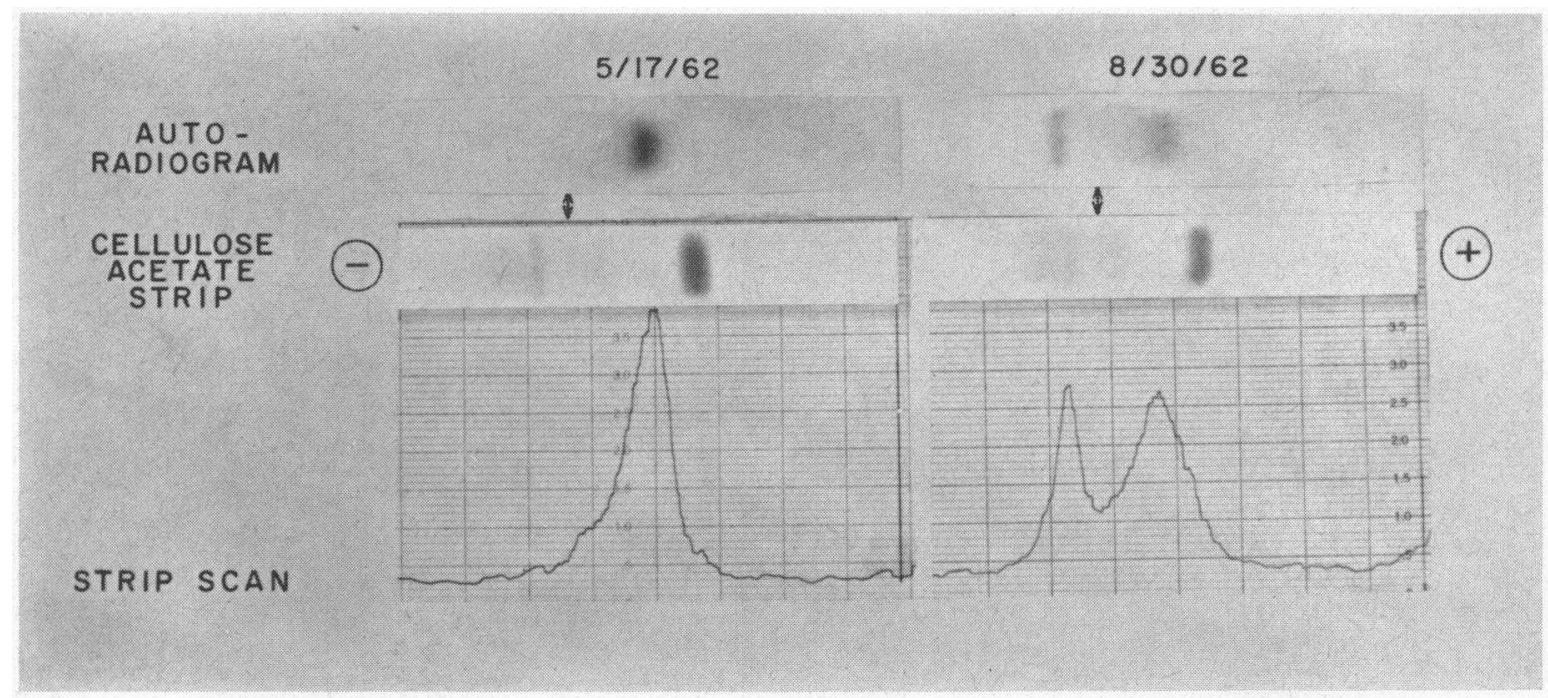

Fig. 4. MigRation OF PORCINE INSULIN- ${ }^{181}$ I (1,750 $\mu$ U PER ML SERUM) DURING ELECTROPHORESIS ON CELLULOSE ACEtate AFter addition to Serum (heifer H 210) OBtained Before (5/17/62) AND AFter (8/30/62) Seven injections OF BOVINE INSULIN IN ADJUVANT.

until 6 months elapsed and a total of 11 injections had been given. A representative example is shown in Figure 4. All of the results obtained up to December 1962 are summarized in Figure 5, except for animal $\mathrm{H} 210$, which died accidentally in November 1962. It is appreciated that the method used allows for only semiquantitative comparisons of antibody levels and that the discrepancy between antibody titers in animals immunized with heterologous or homologous insulin may be much greater than that suggested by a direct comparison of Figures 3 and 5.

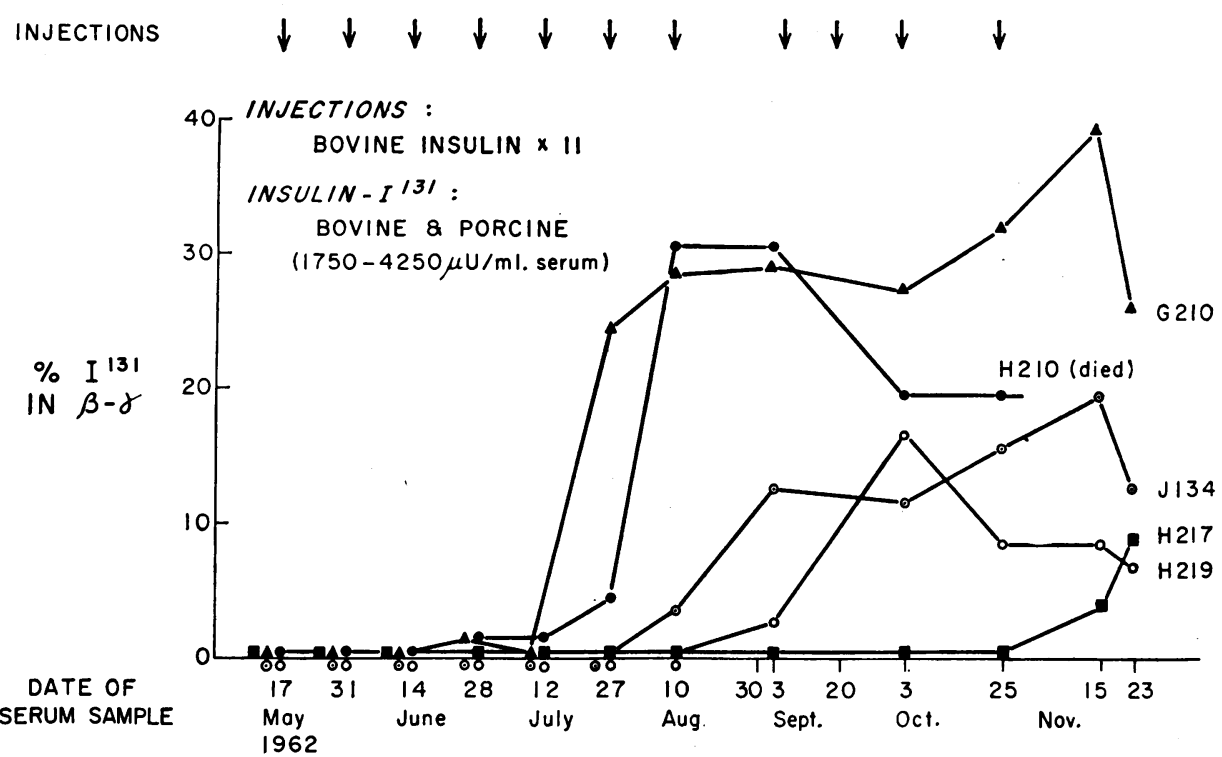

Fig. 5. Migration of ${ }^{131}$ I-labeled insulin (Either bovine or PORCINe) DURing ElectroPHORESIS ON CELLULOSE ACETATE AFTER ADDITION TO SERA FROM FIVE HEIFERS RECEIVING INJECTIONS OF BOVINE INSULIN. Each symbol shows the mean percentage of added labeled hormone (1,750 to $4,250 \mu \mathrm{U}$ per $\mathrm{ml}$ serum) migrating with the $\beta$ - $\gamma$-globulins for any one animal on the day indicated. A separate symbol has been used for each of the five heifers in this group. 
TABLE II

Mean body weights and serum glucose levels observed in the three experimental groups of heifers

\begin{tabular}{|c|c|c|c|c|c|c|c|}
\hline \multirow[b]{2}{*}{ Date } & \multicolumn{3}{|c|}{ Mean body weight* } & & \multicolumn{3}{|c|}{ Mean serum glucose } \\
\hline & $\underset{\text { group }}{\text { Adjuvant }}$ & $\begin{array}{l}\text { Porcine } \\
\text { insulin } \\
\text { group }\end{array}$ & $\begin{array}{l}\text { Bovine } \\
\text { insulin } \\
\text { froup }\end{array}$ & & $\underset{\text { group }}{\text { Adjuvant }}$ & $\begin{array}{l}\text { Porcine } \\
\text { insulin } \\
\text { group }\end{array}$ & $\begin{array}{c}\text { Bovine } \\
\text { insulin } \\
\text { group }\end{array}$ \\
\hline $\begin{array}{r}5 / 17 / 62 \\
5 / 31 / 62 \\
6 / 14 / 62 \\
6 / 28 / 62 \\
7 / 12 / 62 \\
7 / 27 / 62 \\
8 / 9 / 62 \\
10 / 3 / 62 \\
11 / 23 / 62 \\
1 / 24 / 63 \\
3 / 13 / 63 \\
4 / 23 / 63\end{array}$ & $\begin{array}{l}343 \\
382 \\
405 \\
427 \\
465 \\
464 \\
472 \\
538 \\
\\
\\
\\
798 \\
942\end{array}$ & $\begin{array}{c}l b \\
394 \\
428 \\
449 \\
479 \\
509 \\
520 \\
562 \\
611 \\
\\
\\
898 \\
1,014\end{array}$ & $\begin{array}{r}400 \\
427 \\
442 \\
477 \\
510 \\
516 \\
526 \\
621 \\
\\
\\
890 \\
1,005\end{array}$ & & $\begin{array}{l}89 \\
89 \\
73 \\
77 \\
71 \\
77 \\
77 \\
85 \\
76 \\
75 \\
77 \\
71\end{array}$ & $\begin{array}{c}m g / 100 m l \\
88 \\
74 \\
84 \\
75 \\
70 \\
74 \\
76 \\
95 \\
85 \\
85 \\
72 \\
76\end{array}$ & $\begin{array}{l}91 \\
68 \\
80 \\
70 \\
60 \\
74 \\
76 \\
92 \\
88 \\
86 \\
78 \\
75\end{array}$ \\
\hline $\begin{array}{l}\text { Final weight } \\
\text { as per } \\
\text { cent of } \\
\text { base line }\end{array}$ & 275 & 257 & 251 & $\begin{array}{l}\text { Mean } \\
\text { SEM }\end{array}$ & $\begin{array}{r}78 \\
\pm \quad 2\end{array}$ & $\begin{array}{r}80 \\
\pm \quad 2\end{array}$ & $\begin{array}{r}78 \\
\pm 3\end{array}$ \\
\hline
\end{tabular}

* Estimated by measuring tape.

Blood glucose values, weight gain, and local reactions to the injected material. As shown in Table II, significant hypo- or hyperglycemia was never observed. Abnormal behavior of the animals between injections was not observed. Weight gain proceeded at comparable rates in the insulin-injected and the adjuvant-injected groups. Local reactions detectable by palpation and present 2 weeks after the last injection were not noted in the adjuvant-injected animals, occasionally felt in

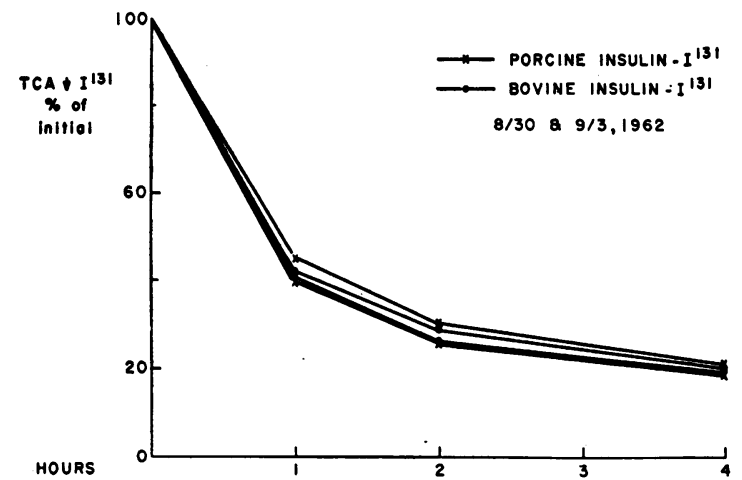

Fig. 6. Disappearance of INJECted bovine or PORCINe

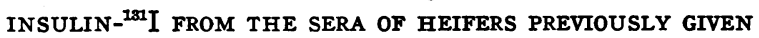
SEVEN INJECTIONS OF ADJUVANT. Trichloroacetic acid (TCA)-precipitable ${ }^{181} \mathrm{I}$ is expressed as percentage of its concentration in the sample drawn 12 minutes after injection of the labeled hormone $(0.8 \mathrm{mc}$ per animal, 0.02 $\mathrm{mg}$ or about $0.5 \mathrm{U}$ ). the bovine group, and frequently observed in the porcine group where they correlated roughly with the magnitude of the $\beta$ - $\gamma$-globulin distribution of insulin- ${ }^{181}$ I added to serum. In a few heifers, the indurations persisted for 6 to 8 weeks.

Disappearance of insulin-131 I from serum in vivo. Whereas insulin-131 I of either porcine or bovine origin disappeared rapidly from the circulation of nonimmunized heifers (Figure 6), delayed disappearance was observed both in the porcine insu-

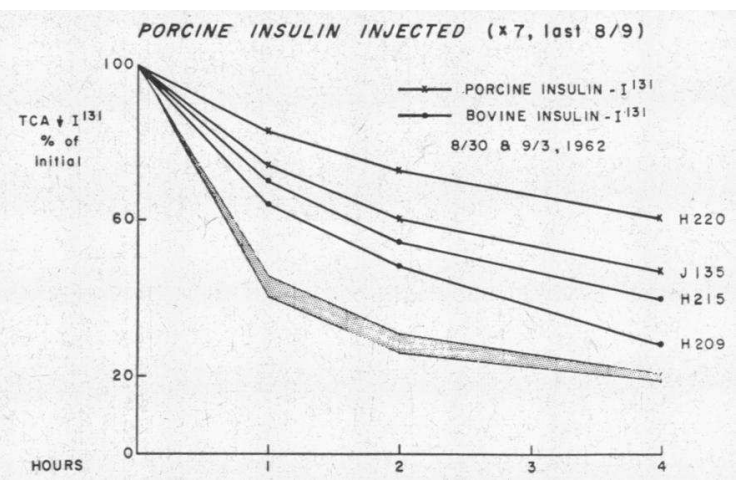

Fig. 7. Disappearance of INJECTEd bovine OR PORCINE INSULIN- ${ }^{181}$ I FROM THE SERA OF HEIFERS PREVIOUSLY GIVEN SEVEN INJECTIONS OF PORCINE INSULIN IN ADJUVANT. TCA-precipitable ${ }^{121} \mathrm{I}$ is expressed as percentage of its concentration in the sample drawn 12 minutes after injection of the labeled hormone $(0.8 \mathrm{mc}$ per animal, 0.02 $\mathrm{mg}$ or about $0.5 \mathrm{U}$ ). The gray area indicates the range of disappearance in the adjuvant controls (Figure 6). 
lin-injected (Figure 7) and the bovine insulin-injected groups (Figure 8 ). In the porcine insulin group, the disappearance of insulin- ${ }^{131} \mathrm{I}$ of both porcine and bovine origin was measured. There appeared to be a slower disappearance with labeled porcine insulin, i.e., with insulin used as antigen. Whether a similar discrepancy is also seen in heifers immunized with bovine insulin was not tested, since we felt that these animals should not receive even tracer doses of porcine insulin during the experiment. A delayed disappearance of bovine insulin-131 I was observed in two of the three animals tested in this group (Figure 8), whereas the third animal ( $\mathrm{H} 217$ ) exhibited a normal disappearance. This was the animal that had

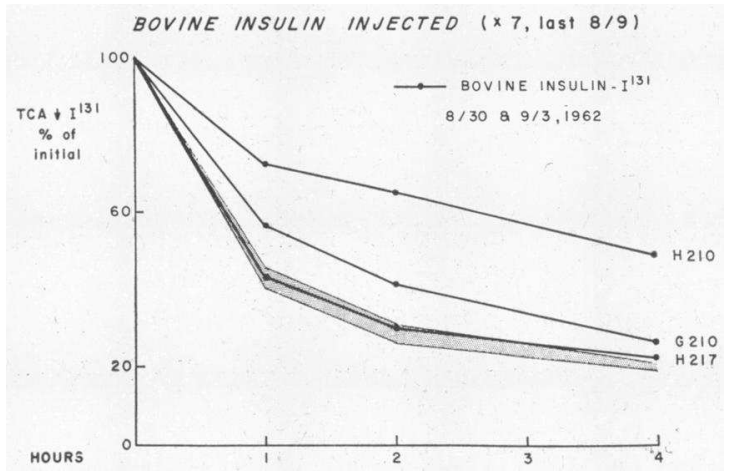

Fig. 8. Disappearance of injected bovine insulin${ }^{131}$ I FROM THE SERA OF HEIFERS PREVIOUSLY GIVEN SEVEN INJECTIONS OF BOVINE INSULIN IN ADJUVANT. TCA-precipitable ${ }^{131} \mathrm{I}$ is expressed as percentage of its concentration in the sample drawn 12 minutes after injection of the labeled hormone $(0.8 \mathrm{mc}$ per animal, $0.02 \mathrm{mg}$ or about $0.5 \mathrm{U})$. The gray area indicates the range of disappearance in the adjuvant controls (Figure 6).

not yet developed $\beta-\gamma$ distribution of insulin- ${ }^{131} \mathrm{I}$ in vitro (Figure 5 ) at the time of the disappearance study.

Effectiveness of crystalline insulin injected in vivo. The biological effectiveness of insulin was tested by intravenous administration of $0.1 \mathrm{U}$ per $\mathrm{kg}$ body weight. The normal response was tested with both bovine and porcine insulin in five animals that had received only adjuvant. As shown in Figure 9, all animals exhibited a rapid blood glucose fall from 72 to $76 \mathrm{mg}$ per $100 \mathrm{ml}$ to values between 23 and $35 \mathrm{mg}$ per $100 \mathrm{ml} \frac{1}{2}$ to 1 hour after the insulin injection, with gradual recovery thereafter. By comparison, the responses provoked by porcine insulin in the porcine group and by bovine

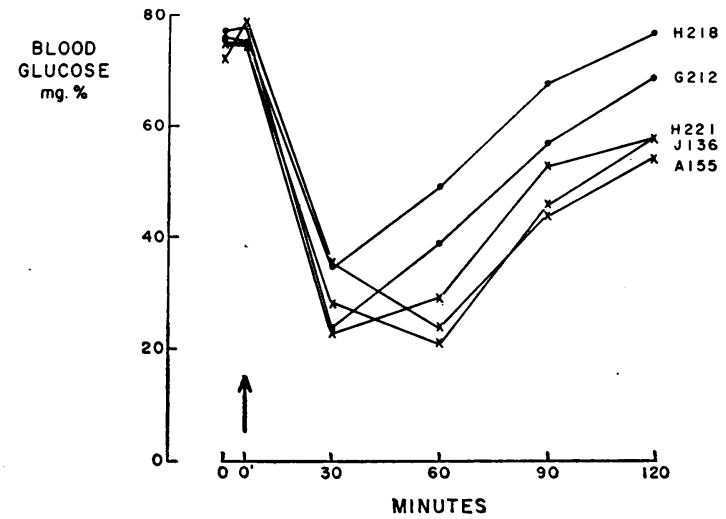

Fig. 9. Blood glucose RESPONSE to bovine ( $\bullet$ ) AND PORCINE $(X)$ INSULIN INJECTED INTRAVENOUSLY (0.1 U PER KG ON 10/3/62) IN FIVE HEIFERS GIVEN NINE INJECTIONS OF ADJUVANT ALONE. Last adjuvant injection was on $9 / 20 / 62$, with test performed on $10 / 3 / 62$.

insulin in the bovine group were smaller (Figures 10 and 11) than in the adjuvant group. One of the animals immunized to porcine insulin ( $\mathrm{H} \mathrm{209}$ ) exhibited rather marked resistance to the intravenous injection of porcine insulin.

Glucose tolerance test. Intravenous glucose tolerance tests were performed in two animals of each group.' These intravenous glucose tolerance tests involved the administration of rather large quantities of $50 \%$ glucose $(300 \mathrm{ml}$ or more). The rate of administration varied between animals, and there was minimal infiltration in one heifer

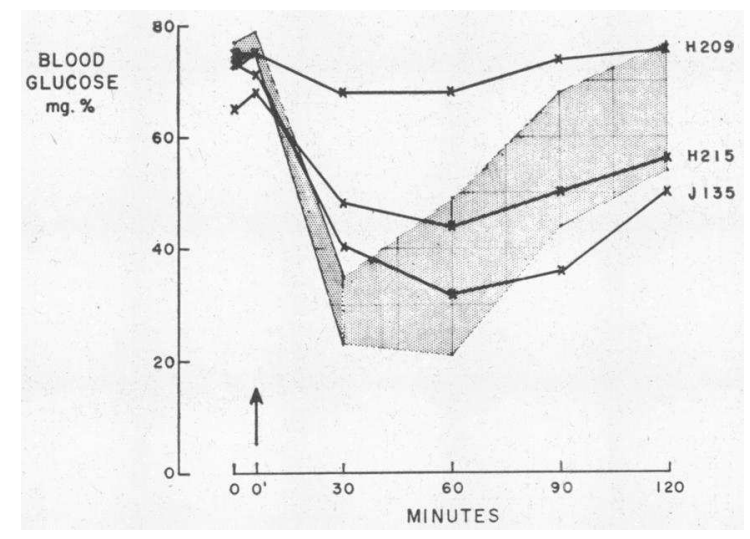

Fig. 10. Blood GLUCOSE RESPONSE to PORCINE INSUlin INJECTED INTRAVENOUSLY (0.1 U PER KG ON 10/3/62) IN THREE HEIFERS PREVIOUSLY GIVEN SEVEN INJECTIONS OF PORCINE INSULIN IN ADJUVANT. Last insulin injection on $9 / 20 / 62$, with test performed on $10 / 3 / 62$. The gray area indicates the range of blood glucose response in the adjuvant controls (Figure 9). 


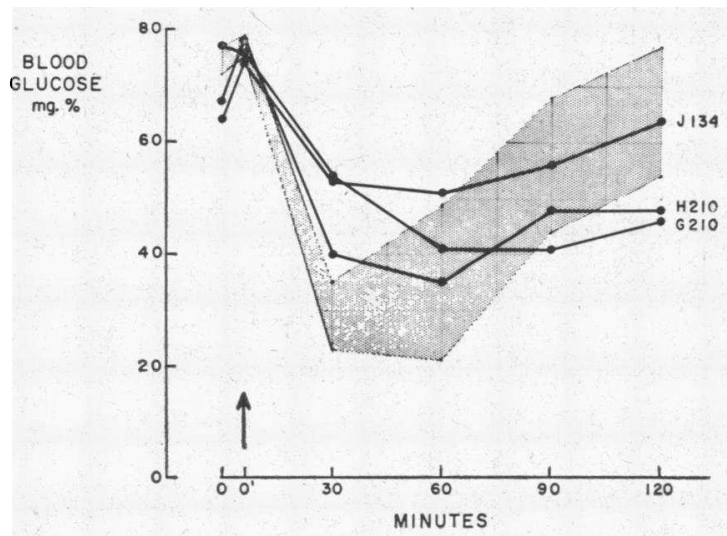

Fig. 11. BloOd GLUCOSE RESPONSE to BOVINE INSULIN INJECTED INTRAVENOUSLY (0.1 U PER KG ON 10/3/62) IN THREE HEIFERS PREVIOUSLY GIVEN NINE INJECTIONS OF BOVINE INSULIN IN ADJUVANT. Last insulin injection on $9 / 20 / 62$, with test carried out on $10 / 3 / 62$. The gray area indicates the range of blood glucose response in the adjuvant controls (Figure 9).

(G 210). Allowing for this, no marked abnormalities were seen (Figure 12).

Insulin-like activity of sera and respective acid ethanol extracts. The insulin-like activity of 30 serum samples and of 30 acid ethanol extracts of the same sera was measured. The results are shown in Table III and may be summarized as follows. Base-line insulin-like activity of $25 \%$ serum from 15 heifers ranged from 15 to $100 \mu \mathrm{U}$ per $\mathrm{ml}$ with a mean of $57 \mu \mathrm{U}$ per $\mathrm{ml}$ or, corrected for dilution, $228 \mu \mathrm{U}$ per $\mathrm{ml}$ serum. Acid ethanol extracts of these sera yielded ILA approximating $59 \%$ of whole serum ILA. The administration of adjuvant alone over a 3-month period did not alter ILA of either serum or respective acid ethanol extract. Immunization with porcine insulin in-

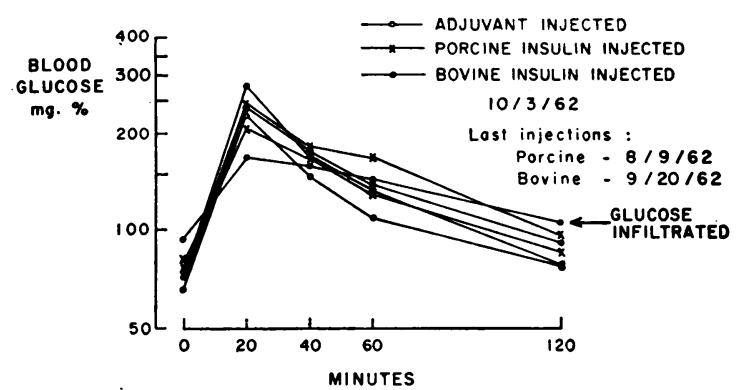

Fig. 12. Intravenous gluCoSe tolerance tests in SiX HEIFERS ( 0.5 G PER KG BODY WEIGHT).

creased the ILA of serum as well as of the acid ethanol extracts. Immunization with bovine insulin similarly increased the ILA of serum and of the acid ethanol extracts.

Relative specificity for insulin-131I of bovine or porcine origin. The data shown in Figure 3 suggest that antibodies found in heifers after immunization with porcine insulin exhibited a greater affinity for ${ }^{131}$ I-labeled insulin of porcine origin. This is demonstrated more clearly in Table IV, which shows an experiment carried out on a single day with bovine and porcine insulin labeled simultaneously and to precisely the same extent. This table also shows that there was no such relative affinity for either of the two labeled insulins in the case of antibodies obtained to homologous (bovine) insulin injected in adjuvant.

\section{Discussion}

An important assumption underlying this study is that the preparation of bovine insulin used was not contaminated by porcine insulin. The special

TABLE III

Mean insulin-like activity (ILA) on rat adipose tissue of $25 \%$ serum diluted with buffer and of the corresponding acid ethanol extracts of the same serum samples*

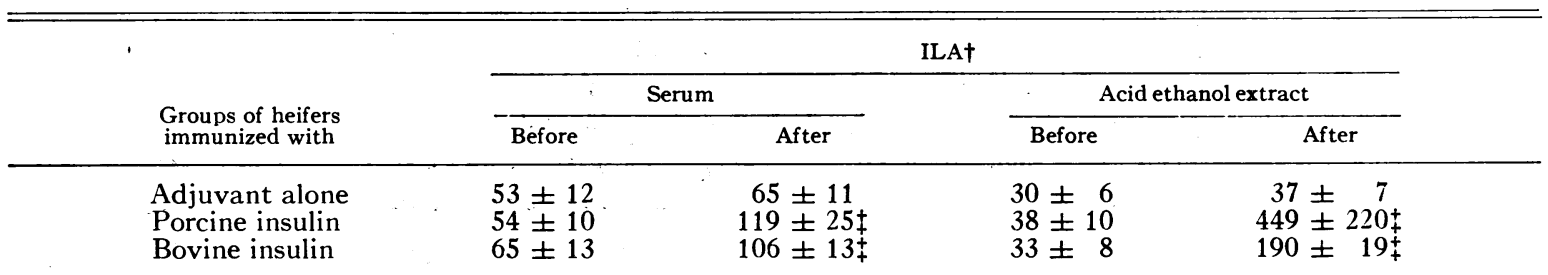

* The sera were obtained from groups of five heifers before $(5 / 10 / 62)$ or after $(8 / 9 / 62)$ repeated injections of adjuvant alone, or of adjuvant containing bovine or porcine insulin.

$\dagger$ Measured in microunits per milliliter $25 \%$ serum or equivalent of extract.

‡ Significantly different $(\mathrm{p}<0.05)$ from the corresponding values obtained before the first insulin injections and at corresponding times from the sera of the animals injected with adjuvant alone. 
TABLE IV

Relative affinity for porcine or bovine insulin-131 I of serum $\beta$ - $\gamma$-globulins from heifers immunized with heterologous (porcine) or homologous (bovine) insulin in adjuvant

\begin{tabular}{|c|c|c|c|}
\hline & & \multicolumn{2}{|c|}{ 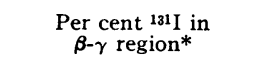 } \\
\hline Animal no. & $\begin{array}{l}\text { Sample } \\
\text { date, } \\
1962\end{array}$ & $\begin{array}{c}\text { Porcine } \\
\text { insulin-131 } \\
(3,750 \\
\mu \mathrm{U} \text { per } \mathrm{ml})\end{array}$ & $\begin{array}{c}\text { Bovine } \\
\text { insulin-131 } \\
(3,750 \\
\mu \mathrm{U} \text { per } \mathrm{ml})\end{array}$ \\
\hline
\end{tabular}

Animals immunized with porcine insulin

\begin{tabular}{|c|c|c|}
\hline $\begin{array}{ll}\mathrm{H} & 209 \\
\mathrm{H} & 215 \\
\mathrm{H} & 220 \\
\mathrm{G} & 211 \\
\mathrm{~J} & 135\end{array}$ & $\begin{array}{r}10 / 3 \\
10 / 3 \\
8 / 10 \\
8 / 10 \\
10 / 3\end{array}$ & $\begin{array}{l}61 \\
45 \\
82 \dagger \\
71 \\
19\end{array}$ \\
\hline lea & & 55.6 \\
\hline
\end{tabular}

Animals immunized with bovine insulin

\begin{tabular}{|c|c|c|}
\hline $\begin{array}{cc}\mathrm{H} & 210 \\
\mathrm{H} & 219 \\
\mathrm{G} & 210 \\
\mathrm{~J} & 13 \pm \\
\mathrm{H} & 217\end{array}$ & $\begin{array}{ll}10 / & 3 \\
10 / & 3 \\
10 / 3 \\
10 / 3 \\
10 / 3\end{array}$ & $\begin{array}{r}22 \\
19 \\
19 \\
10 \\
0\end{array}$ \\
\hline Mean & & 14.0 \\
\hline
\end{tabular}

* Data expressed as per cent ${ }^{131}$ I found in the $\beta-\gamma$ region after electrophoresis of serum insulin-131I incubate on cellulose acetate strips.

$\dagger 1,750 \mu \mathrm{U}$ per $\mathrm{ml}$ insulin- ${ }^{-131} \mathrm{I}$.

precautions that justify this assumption have been described in Methods. Furthermore, the homologous (bovine) insulin ${ }^{1}$ that we used, the homologous (porcine) insulin ${ }^{4}$ used by Lockwood and Prout (14), and that used by Brunfeldt and Deckert $(15),{ }^{5}$ were supplied by three independent manufacturers, using different insulin preparation and purification procedures.

An immunological response to crystalline insulin in adjuvant administered over several months was elicited in the bovine species. In the case of immunization with heterologous insulin, this is an expected response and occurred within 2 to 4 weeks. This is evidenced by the appearance of binding of insulin- ${ }^{131}$ incubated with serum in the region of the $\beta-\gamma$-globulins. The $\beta-\gamma$ binding was seen with either porcine or bovine insulin-181 I and, in some of the sera, this cross reaction with bovine insulin has subsequently been confirmed with immunodiffusion techniques, by employing either agar microelectrophoresis of whole serum or partially purified $\gamma$-globulin with subsequent diffusion against crystalline bovine insulin (20), or straight diffusion of serum in agar gel against solu-

\footnotetext{
4 E. R. Squibb and Sons, New York, N. Y.
}

5 Nordisk Insulinlaboratorium, Copenhagen, Denmark. tions of crystalline bovine insulin (20). Cattle, therefore, should be added to the list of species in which immunization with heterologous insulin leads to the production of one or more antibodies that cross-react with the extracted pancreatic insulin of the immunized species (21). Furthermore, the results obtained with the administration of insulin in vivo (Figure 10) suggest that the antibody reaction with heterologous insulin leads to its decreased biological effectiveness. The finding of larger quantities of ILA in the acid ethanol extract of serum than in native serum (Table III) suggests that a significant fraction of circulating insulin-like activity had been bound and neutralized by antibody. However, it is uncertain whether the insulin so bound is of exogenous or endogenous origin, although it has been recently observed that antibodies to exogenous insulin are, in certain instances, capable of binding endogenous insulin produced by the immunized animal (22). The presence of normal glucose tolerance found in these immunized cattle is similar to normal glucose tolerance in insulin-immunized guinea pigs (23). These observations are compatible with the concept that complete equilibrium between insulin and its antibody requires considerably more time than the duration of a glucose tolerance test.

In heifers injected with bovine (homologous) insulin in adjuvant, an immunological response was also seen; however, it required a more prolonged course of repeated injections and seldom reached levels comparable to those induced by porcine insulin. Again, $\beta-\gamma$-globulin binding of both bovine and porcine insulin-131I occurred (Figure $5)$. The appearance of the $\beta-\gamma$-globulin binding coincided with a prolonged half-life of insulin${ }^{131}$ I injected in vivo (Figure 8) and with decreased biological activity of bovine insulin injected in vivo (Figure 11). Immunoelectrophoresis of bovine serum against antibovine serum produced in rabbits confirmed that the binding of insulin- ${ }^{131}$ I was to $\beta$ - $\gamma$-globulins. The latter observations, which have been reported elsewhere (20), were entirely comparable to the results obtained by the same technique in serum from the heifers immunized with porcine (heterologous) insulin. However, precipitating antibodies to insulin could not be detected by immunodiffusion techniques in the animals immunized with bovine insulin, whereas 
they were demonstrable in two heifers immunized with porcine insulin ( $\mathrm{H} \mathrm{209,} \mathrm{G} \mathrm{211).} \mathrm{The} \mathrm{rela-}$ tively infrequent occurrence of such precipitating antibodies in the case of immunization with insulin is well known. Thus, although there are many similarities in the responses of heifers to either injected homologous (bovine) or heterologous (porcine) insulin, differences have also been noted. They are related to the onset and magnitude of antibody formation, the lack of precipitating antibodies in the small sample studied so far, and a lesser degree of relative specificity for insulin- ${ }^{131} \mathrm{I}$ of bovine or porcine origin (Table IV). The possibility that the porcine insulin-treated heifers possess an antibody different from that present in the bovine insulin-injected animals must be considered.

Extracted and crystallized pancreatic insulin was employed in this study. It is possible that these procedures produce antigenicity. Also, it is possible for any protein preparation, however pure, to contain traces of contaminating yet closely related proteins that may be undetectable by available physical and chemical techniques, yet immunologically active. Furthermore, insulin was injected in adjuvant. It is possible that the insulin was modified by its exposure to adjuvant or to the subcutaneous inflammatory reaction produced by adjuvant. However, Brunfeldt and Deckert (15) have reported production of insulin antibodies by the administration of crystalline pork insulin without adjuvant in one pig injected daily for 87 days. It would seem, therefore, that immunological reaction to homologous insulin is not dependent upon presence of adjuvant, nor is it limited to the bovine species $(14,15)$. The antigenicity of pure porcine insulin in man has been studied by Berson and Yalow (24), since porcine insulin differs from human by only one amino acid at the $C$ terminal of the $\beta$ chain. They observed that porcine insulin is antigenic in man, and that the antibodies formed react with porcine and human insulin and also with porcine insulin from which the last eight amino acids from the $C$ terminal of the $\beta$ chain had been removed. They concluded that the antigenic determinant of porcine insulin in man must be located in a part of the molecule where the amino acid sequence is identical to the corresponding part of the human insulin molecule.
The studies that have been cited and the data presented here establish the antigenic activity of homologous extracted pancreatic insulin preparations injected subcutaneously. Since the production of antibodies by endogenous circulating insulin has not been demonstrated, it is reasonable to assume that purified crystalline pancreatic insulin, injected subcutaneously, differs antigenically from serum insulin. The differences that might exist between the two types of insulin remain conjectural. Whereas they might be artifactual, as discussed at the beginning of the preceding paragraph, they might also be real. In favor of the latter possibility is the fact that specially prepared insulin preparations are among the purest protein preparations available today.

Two important implications of these admittedly tentative conclusions should be pointed out. First, if endogenous serum insulin or insulins are not antigenic when compared with crystalline pancreatic insulin, then the ability of a protein to react with antibodies to pancreatic insulin should not be taken as the sole criterion of its identification as insulin. Secondly, discussions of the discrepancies that exist between the levels of serum "insulin" obtained by immunoassay and by bioassay procedures have usually pointed out that the levels measured by bioassay are artifactually large. However, it is also possible that the levels measured with immunoassay procedures are artifactually small, since antibodies to pancreatic insulin may not be able to react with parts of circulating insulin, or may react differently with that portion of serum insulin with which they indisputably react $(7,9,10)$. For example, if the state of polymerization of endogenous serum insulin differed from that of extracted pancreatic insulin added to serum, reaction with antibodies to the latter would probably occur, but quantitative deductions drawn from systems utilizing ${ }^{181}$ I-labeled pancreatic insulin as marker and crystalline pancreatic insulin as reference standard would very likely be in error. Whereas we feel compelled to indicate the existence of these uncertainties, a more extensive discussion appears inappropriate, since the prevailing differences of opinion will only be resolved when the precise physical and chemical nature of endogenous insulin or insulins in plasma is known.

Finally, these studies may deserve special emphasis because of an additional finding that will be 
reported and discussed elsewhere in detail. Seven of the animals reported here have been autopsied, two of the adjuvant-injected group, two of the porcine insulin-injected group, and three of the bovine insulin-injected group. Whereas the pancreas of the adjuvant-injected animals did not differ from normal, i.e., from the appearance of a series of pancreas samples obtained at random at the slaughter house, clear-cut anomalies were seen in all of the insulin-immunized cows, whether immunized with homologous or heterologous insulin. The anomalies consisted of striking lymphocytic infiltration and fibrosis strictly limited to the islets of Langerhans with early and, in two instances, advanced scarring $(20,25,26)$. These histologic findings resembled those seen in the instances of so-called insulitis that have been described in early severe juvenile diabetes mellitus in man, particularly when examination was carried out within a few weeks, or at most, months, of the beginning of diabetic symptoms (27-29).

\section{Summary}

It has been generally assumed that the antigenicity of insulin is the result of differences in the structure of insulin obtained from different species. The experiments described have been designed to examine this hypothesis by testing the antigenicity of porcine and bovine insulin in five heifers each with five additional heifers serving as adjuvant controls. An immunological response to the repeated administration of both heterologous (porcine) and homologous (bovine) insulin in adjuvant was observed in all insulin-injected animals. However, the response to the heterologous insulin in adjuvant was both more rapid and more pronounced. There was no response to the injection of adjuvant alone.

The evidence for the immunological nature of the response was derived from 1 ) changes in the electrophoretic distribution of insulin-131I added to serum; 2) delayed disappearance of insulin- ${ }^{131} \mathrm{I}$ from serum in vivo; 3) decreased hypoglycemic activity of insulin in vivo; 4) increase in the acid ethanol extractable insulin-like activity of serum with a lesser increase in the insulin-like activity of unextracted serum; and 5) in some instances, the presence of precipitating antibodies to insulin, although this was observed only in two of five animals immunized with heterologous insulin (20).
As reported in detail elsewhere $(25,26)$ the pancreas of five animals immunized with insulin in adjuvant, either homologous or heterologous, exhibited striking lymphocytic infiltration and fibrosis limited to the islets of Langerhans.

The glucose tolerance of the cattle remained normal.

These findings raise important questions as to the identity of extracted pancreatic insulin with circulating insulin in plasma, and also suggest that the possible significance of immunopathological reactions of the endocrine pancreas to insulin warrants further consideration.

\section{References}

1. Tuft, L. Insulin hypersensitiveness; immunologic considerations and case reports. Amer. J. med. Sci. 1928, 176, 707.

2. Moloney, P. J. Antibodies to insulin in The Mechanism of Action of Insulin, a Symposium, F. G. Young, W. A. Broom, and F. W. Wolff, Eds. Oxford, Blackwell, 1960, p. 201.

3. Yalow, R. S., and S. A. Berson. Immunologic aspects of insulin. Amer. J. Med. 1961, 31, 882.

4. Arquilla, E. R. Immunological studies of insulin in Immunoassays, vol. 14 of Ciba Foundation Colloquia on Endocrinology, G. E. W. Wolstenholme and M. Cameron, Eds. London, Churchill, 1962, p. 146.

5. Prout, T. E. The chemical structure of insulin in relation to biological activity and to antigenicity. Metabolism 1963, 12, 673.

6. Banting, F. G., W. R. Franks, and S. Gairns. Physiological studies in metrazole shock. VII. Anti-insulin activity of insulin-treated patient. Amer. J. Psychiat. 1938, 95, 562.

7. Moloney, P. J., and M. Coval. Antigenicity of insulin: diabetes induced by specific antibodies. Biochem. J. 1955, 59, 179.

8. Moloney, P. J., and L. Goldsmith. On the antigenicity of insulin. Canad. J. Biochem. 1957, 35, 79.

9. Wright, P. H. The production of experimental diabetes by means of insulin antibodies. Amer. J. Med. 1961, 31, 892.

10. Cunningham, N. F., D. S. P. Patterson, and P. H. Wright. Acute insulin deficiency provoked in sheep and cows by single injections of anti-insulin serum. J. Physiol. (Lond.) 1963, 169, 137.

11. Renold, A. E., J. Steinke, J. S.. Soeldner, R. E. Smith, and H. N. Antoniades. Response of calves and heifers to the prolonged administration of porcine and bovine insulin (abstract). Vox Sang. (Basel) 1963, 8, 121.

12. Renold, A. E., J. Steinke, J. S. Soeldner, R. E. Smith, and $H$. N. Antoniades. Immunologic response of 
heifers to the administration of porcine and bovine (homologous) insulin (abstract). J. clin. Invest. $1963,42,969$.

13. Lockwood, D. H., and T. E. Prout. Isoantibodies to insulin (abstract). Clin. Res. 1962, 10, 401.

14. Lockwood, D. H., and T. E. Prout. Antigenicity of heterologous and homologous insulin. Metabolism $1965,14,530$.

15. Brunfeldt, K., and T. Deckert. Antibodies in the pig against pig insulin. Acta endocr. (Kbh.) 1964, 47, 367.

16. Freedlender, A. E., S. B. Rees, and J. S. Soeldner. Some physical-chemical variables affecting insulin migration in vitro. I. Electrophoresis. Proc. Soc. exp. Biol. (N. Y.) 1964, 115, 21.

17. Somogyi, M. Notes on sugar determination. J. biol. Chem. 1952, 195, 19.

18. Renold, A. E., D. B. Martin, Y. M. Dagenais, J. Steinke, R. J. Nickerson, and M. C. Sheps. Measurement of small quantities of insulin-like activity using rat adipose tissue. I. A proposed procedure. J. clin. Invest. 1960, 39, 1487.

19. Steinke, J., J. S. Soeldner, and A. E. Renold. Measurement of small quantities of insulin-like activity with rat adipose tissue. IV. Serum insulinlike activity and tumor insulin content in patients with functioning islet-cell tumors. J. clin. Invest. 1963, 42, 1322.

20. Renold, A. E., J. S. Soeldner, and J. Steinke. Immunological studies with homologous and heterologous pancreatic insulin in the cow in Ciba Founda- tion Colloquia on Endocrinology, M. Cameron and M. O'Connor, Eds. London, Churchill, 1964, vol. 15, p. 122.

21. Moloney, P. J. Endogenous and pancreatic insulins in Immunoassays, vol. 14 of Ciba Foundation Colloquia on Endocrinology, G. E. W. Wolstenholme and M. Cameron, Eds. 1962, p. 169.

22. Grodsky, G. M. Production of autoantibodies to insulin in man and rabbits. Diabetes 1965, 14, 396.

23. Galansino, G., G. Guidotti, A. Parmeggiani, D. Kanameishi, D. Billinger, and P. P. Foà. Failure to alter glucose tolerance in the guinea pig by active immunization with bovine insulin. Endocrinology 1963, 73, 120.

24. Berson, S. A., and R. S. Yalow. Antigens in insulin. Determinants of specificity of porcine insulin in man. Science 1963, 139, 844.

25. Renold, A. E., J. Steinke, J. S. Soeldner, A. Gonet, and P. M. LeCompte. Experimental insulitis in heifers in Immunopathology, 4th International Symposium, P. A. Miescher and P. Grabar, Eds. Basel, Benno Schwabe, 1966, p. 349.

26. LeCompte, P. M., J. Steinke, J. S. Soeldner, and A. E. Renold. Changes in islets of Langerhans in insulin-injected cows. Diabetes, in press.

27. Von Meyenburg, H. Ueber "insulitis" bei Diabetes. Schweiz. med. Wschr. 1940, 21, 554.

28. Warren, S. The pathology of diabetes in children. J. Amer. med. Ass. 1927, 88, 99.

29. LeCompte, P. M. "Insulitis" in early juvenile diabetes. Arch. Path. 1958, 66, 450. 